\title{
Could the System Side Knowledge towards Hepatitis B be Translated to the Demand Side: A Cross-Sectional Evaluation in Sabarkantha, Gujarat
}

\author{
Farjana Memon ${ }^{1, *}$, Sandul Yasobant ${ }^{1}$, Sushil Patel $^{2}$, Deepak Saxena ${ }^{1}$, Mayur Patel ${ }^{3}$, Yash Patel ${ }^{3}$
}

\begin{abstract}
Introduction: Hepatitis B is the world's prevalent blood-borne viral infection, specifically it is prevalent with its two flip sides of the coin such as in health care workers and pregnant women. Since health care workers have a vital role in providing health care, thus are more vulnerable to occupational risk. On the flip side, the most common method of transmission of $\mathrm{HBV}$ around the world is from mother to infant. Hence, both population knowledge and practice should be at an optimal level. The purpose of this study was to assess the influence of the system side knowledge and practice towards Hepatitis B be on the demand-side population in Sabarkantha, Gujarat. Materials and Methods: This cross-sectional study was carried out in the Sabarkantha district of Gujarat. Data were obtained by using a piloted structured questionnaire in vernacular language from the supply-side (health workers) and demand-side (antenatal/ postnatal mothers) to assess the Knowledge of Hepatitis B at a point in time. Results: Study found $6.14( \pm 2.89)$ and $1.69( \pm 1.7)$ mean knowledge score (total score=14) towards the Hepatitis B disease, in the supply-side population and in the demand-side population respectively. The difference was statistically significant. In both populations, the most usual knowledge for symptoms and transmission of hepatitis reported were for Jaundice and hepatitis vaccine. Though the $60.9 \%$ ANC/PNC revealed ASHA, as the most common source of information, the influence of ASHA's knowledge on ANC/PNC was not up to the mark. Furthermore, the study noticed ambiguity between Hepatitis A, E and Hepatitis B knowledge in both populations. Conclusion: There is need of frequent context tailored training of Hepatitis $B$ amongst supply-side workers.

Key words: HBsAg, Hepatitis B, ASHA, ANC/PNC, KAP.
\end{abstract}

\section{Farjana Memon ${ }^{1, *}$, Sandul Yasobant ${ }^{1}$, Sushil Patel ${ }^{2}$, Deepak Saxena ${ }^{1}$, Mayur Patel $^{3}$, Yash Patel ${ }^{3}$ \\ 'Indian Institute of Public Health Gandhinagar, Gujarat, INDIA. ${ }^{2}$ Akshar Diabetes Centre, Vadodara, Gujarat, INDIA. \\ ${ }^{3}$ Swasthya Diabetes Care, Ahmedabad, Gujarat, INDIA. \\ Correspondence \\ Prof (Dr.) Deepak Saxena \\ Indian Institute of Public Health \\ Gandhinagar (IIPHG), Opp. Air - Force \\ Head Quarters, Nr. Lekawada, \\ Gandhinagar, Gujarat, INDIA. \\ Phone no: +91-9327396717 \\ Email: ddeepak72@iiphg.org \\ History \\ - Submission Date: 05 -05-2021 \\ - Revised Date: 24-06-2021 \\ - Accepted Date: 10-07-2021}

DOI : 10.5530/ijmedph.2021.4.35

Article Available online

http://www.jjmedph.org/v11/i4

\section{Copyright}

(c) 2021 Phcog.Net. This is an openaccess article distributed under the terms of the Creative Commons Attribution 4.0 International license.

\section{INTRODUCTION}

Hepatitis B virus (HBV) is a serious global public health problem, was the $7^{\text {th }}$ leading cause of global mortality in 2015, exceed the number of deaths caused by HIV, tuberculosis, and malaria infection. ${ }^{1,2}$ Hepatitis B infection is reported worldwide but, in some regions, it is endemic, especially in Asia and Africa. The prevalence of $\mathrm{HBV}$ infection in India is estimated to be between 3 to $4.2 \%$, in the general population; In pregnant women, it is 2 to $7.7 \%$ which is very high in comparison to world prevalence amongst pregnant women (1.5 to $2.5 \%) .{ }^{3,4}$ The government of India has set a goal for the prevention and control of viral hepatitis to achieve Sustainable Development Goal (SDG) 3.3 which aims to end viral Hepatitis By 2030, ${ }^{5}$ will require a significant scale-up of prevention and screening efforts in India with a focus on efforts on Awareness regarding Hepatitis B prevention and mode of transmission among the high-risk populations.

$\mathrm{HBV}$ is prevalent with its two flip sides of the coin such as in health care workers and pregnant women ${ }^{6-8}$
Among health care workers Hepatitis B prevalence is two to four folds higher than that of the general population. ${ }^{9}$ Besides that, Nurses and midwives have a vital role in the providing of treatment, education about the nature of the disease, diagnosis, prevention, and timely administration of immunoglobulins and health-related behaviours are affected by different aspects of knowledge, attitude, and practices (KAP). Moreover, evidence shows that the most common method of transmission of HBV around the world is from mother to infant, about one in 25 children born in India develop chronic Hepatitis B infection. The likelihood of developing chronic HBV infection is inversely proportional to the age at the time of HBV exposure. ${ }^{10-12}$ Routine prenatal screening, vaccination to all pregnant women and children, antiviral therapy in mothers with high viral load, perinatal interventions (Hepatitis B immunoglobulin and $\mathrm{HBV}$ vaccination) for the new-borns of infected mothers can prevent a significant number of new infections and the subsequent development of chronic HBV infection. It is highly cost-effective as well. ${ }^{2-5}$
Cite this article : Memon F, Yasobant S, Patel S, Saxena D, Patel M, Patel Y. Could the System Side Knowledge towards Hepatitis B be Translated to the Demand Side: A Cross-Sectional Evaluation in Sabarkantha Gujarat. Int J Med Public Health. 2021;11(4):185-9. 
Therefore, to implement an effective management plan, nurses and midwives along with community people should have an optimal basic understanding of the disease and knowledge of safe practices. ${ }^{13}$ ASHA is the first helping hands in the community and an essential link between the community and the health care provider. The study reveals the success of many public healthcare programmes in India depends on how well is the ASHAs knowledge. Research also shows that high client satisfaction and consistent use of health care service are hinged on the trained healthcare staff ${ }^{14-16}$ Moreover, awareness for any programme or any preventive measure should include participation and buy-in from community members too ${ }^{17,18}$ The very scattered study found to evaluate the KAP and influence of system side knowledge on demand-side population. This study aimed to take a snapshot of these two important sub-populations i.e. health care workers and ANC/PNC women at the same time.

\section{MATERIALS AND METHODS}

\section{Study design and Setting}

This study adopted a cross-sectional design. It was carried out during May-December 2019 in health institution and community to assess the knowledge and attitude towards Hepatitis B of system side and demand side respectively in the Sabarkantha district of Gujarat.

\section{Study Participants}

This study had recruited 60 ASHA from in health facilities and 300 ANC/ PNC women of corresponding ASHA from the community to assess the knowledge in supply-side and demand side as well at a point of time. Out of 60 ASHA and 300 ANC/PNC, 2 ASHA and 9 ANC/PNC were not available during the data collection periods. So final participants of the study were 58 ASHA and 281 ANC/PNC.

\section{Method of Sample size selection}

Both ASHA from the health system and ANC/PNC from the community were selected by cluster randomization. A total of 30 clusters were selected from the selected Taluka. For the health system survey (supply side) 2 ASHA from each cluster i.e. a total of 60 ASHA and for community survey (demand-side) $5 \mathrm{ANC/PNC}$ which was registered and available under each concerned ASHA, i.e. total of $300 \mathrm{ANC} / \mathrm{PNC}$ had been selected from the community of selected block. Out of 60 selected ASHA and $300 \mathrm{ANC} / \mathrm{PNC}, 2 \mathrm{ASHA}$ and 9 ANC/PNC could not participate in the study due to their unavailability during the data collection period.

\section{Data collection and outcome measures}

Data was collected by using a piloted structured questionnaire in vernacular language. The outcome was measured by the knowledge and attitude in both supply and demand side populations at the same point in time. This was further measured coefficient $\left(r^{2}\right)$ to assess the influence of supply-side knowledge on demand-side populations.

\section{Statistical analyses}

Data were entered in MS Excel and analysed in SPSS version 20. Data were analysed in terms of mean knowledge score, the frequency for each variable and coefficient. The mean knowledge score for both populations was calculated by counted all correct response as one of each respondent and sum up all correct answer of each respondent. Finally mean score was calculated by using the independent sample " $t$ " test.

\section{RESULTS}

The result is presented in three items

1. Findings from the supply side evaluation (ASHAs)
2. Findings from the demand side evaluation (ANC/PNC mothers)

3. Influence of supply-side knowledge on demand side participants

\section{Findings from the supply side evaluation (ASHAs)}

Table 1 describes the mean age of the study supply-side population (ASHA) was $34( \pm 7.81)$ years. The mean years of experience were 7 ( \pm 3.8$)$ years. The majority of all selected ASHA (60\%) were completed their education up to secondary school. Half of the participants (55.2\%) were taken Hepatitis B vaccination and among them, only $10.3 \%$ of participants were taken all three doses.

Table 2 describes level of Awareness about Hepatitis B amongst the selected ASHA. It was revealed that $96.6 \%$ of participants were heard about Hepatitis B. At the same time, it was also found that approximately half of the participants knew about it is an infectious disease and 0nly small proportion of participants (20.7\%) knew that it effects on liver. The study reported on an average participant could answer six questions out of a total of fourteen questions for Hepatitis B. The questions were about the Method of transmission (5), symptoms (4), Prevention method (4) and child vaccination dose for Hepatitis B (1).

In the method of Transmission and prevention method, it was found that participants had more knowledge of blood and blood-related products in comparison to unprotected sex. The majority of the participants reported vaccination $(79.3 \%)$ as a prevention method of Hepatitis B. The most common awareness for the symptoms of Hepatitis B found for yellow colouration of the skin, eye (65.5\%), and then for fever (53.4\%). The study reported a good amount of responses for contaminated water and food as a transmission of Hepatitis B and same for prevention method, which shows that participants had confusion between hepatitis A, E and Hepatitis B

The study reported $79.3 \%$ and $24.1 \%$ awareness for birth dose and correct schedule for child vaccination of Hepatitis B respectively. Practically 98.3 $\%$ ASHA counsel for institutional delivery and child immunization to ANC.

Table 3 describes 281 ANC/PNC were enrolled in this study to assess the demand side KAP regarding Hepatitis B, among that $51.2 \%$ were ANC while $48.8 \%$ were PNC. Their mean age was $25( \pm 3.54)$ years. The majority of the participants were from SC/ST/OBC whereas only $10.3 \%$ from the open category. The majority of the participants (54.4\%) were completed education up to secondary school. $87.9 \%$ of ANC/PNC were Housewife and $57.7 \%$ had BPL card

Regarding reproductive history, $89.3 \%$ reported for live births, 96.8 for private or Government institutional delivery and $80 \%$ were delivered normally. Among selected participants, $91.08 \%$ of ANC/PNC had Mamata card and found a record for the Hepatitis B status, among them $83.6 \%$ were nonreactive while and $0.7 \%$ were reactive. Among all enrolled participants $13.5 \%$ knew that they had taken one or two-dose of Hepatitis B vaccination.

\begin{tabular}{|c|c|c|}
\hline Variable & Type & Frequency (n) \\
\hline Age & Mean age of participants & $34 \pm 7.81$ \\
\hline \multirow[t]{2}{*}{ Experience } & Mean years of Experience & $7 \pm 3.8$ \\
\hline & Secondary & $35(60.3)$ \\
\hline \multirow[t]{2}{*}{ Education } & Higher Secondary & $18(31)$ \\
\hline & Graduate & $5(8.6)$ \\
\hline Taken Hepatitis B vaccine & Yes & $32(55.2)$ \\
\hline Complete vaccination & Three doses & $6(10.3)$ \\
\hline
\end{tabular}




\begin{tabular}{|c|c|c|}
\hline Variable & Type of Variable & $\begin{array}{l}\text { Frequency } \\
(\mathrm{n}=58)(\%)\end{array}$ \\
\hline \multirow[b]{2}{*}{ Mean score of knowledge } & Hepatitis B disease in general & $6.14 \pm 2.89$ \\
\hline & $\begin{array}{l}\text { Hep B disease in general plus hep } \\
\text { B program }\end{array}$ & $9.03 \pm 3.07$ \\
\hline Heard about Hepatitis B & Yes & $56(96.6)$ \\
\hline $\begin{array}{l}\text { Awareness about type of } \\
\text { disease }\end{array}$ & Infectious disease & $33(56.9)$ \\
\hline $\begin{array}{l}\text { Awareness about affected } \\
\text { organ }\end{array}$ & Liver & $12(20.7)$ \\
\hline \multirow{5}{*}{$\begin{array}{l}\text { Knowledge regarding } \\
\text { Transmission of Hep B }\end{array}$} & Blood-related products & $25(43.1)$ \\
\hline & Infected Needle & $23(39.7)$ \\
\hline & Unprotected sex & $13(22.4)$ \\
\hline & Mother to child & $9(15.5)$ \\
\hline & Skin to skin(biting) & $3(5.2)$ \\
\hline \multirow{4}{*}{$\begin{array}{l}\text { Knowledge Regarding } \\
\text { Symptoms of Hep B }\end{array}$} & Yellow colour skin, urine, eyes & $38(65.5)$ \\
\hline & Loss of appetite & $5(8.6)$ \\
\hline & Fever & $31(53.4)$ \\
\hline & Nausea/vomiting & $25(43.1)$ \\
\hline \multirow{4}{*}{$\begin{array}{l}\text { Knowledge Prevention } \\
\text { of Hep B }\end{array}$} & Vaccination & $46(79.3)$ \\
\hline & Proper disposed of syringe/needle & $3(5.2)$ \\
\hline & Avoid Injection & $4(6.9)$ \\
\hline & Avoid multiple sex & $5(8.6)$ \\
\hline $\begin{array}{l}\text { awareness about } \\
\text { vaccination }\end{array}$ & Children dose & $25(43.1)$ \\
\hline $\begin{array}{c}\text { Awareness about birth } \\
\text { dose }\end{array}$ & Immediate after birth & $46(79.3)$ \\
\hline Correct schedule & $6^{\text {th }}, 10^{\text {th }}$ and $14^{\text {th }}$ week & $14(24.1)$ \\
\hline $\begin{array}{l}\text { Awareness about } \\
\text { screening test }\end{array}$ & Yes & $50(86.2)$ \\
\hline $\begin{array}{l}\text { Ever received training } \\
\text { of } \mathrm{HB}\end{array}$ & Yes & $40(69.0)$ \\
\hline
\end{tabular}

Table 4 describes level of Awareness about Hepatitis B amongst the selected ANC/PNC. Study found on an average knowledge for 1 to 2 questions out of total 14 questions, which includes ever heard about this disease, method of transmission, symptoms, prevention methods and knowledge about child vaccination. The on-demand side also studies documented most common awareness for jaundice (yellow colouration of skin and eye) with the term of Hepatitis B and vaccination as a prevention method. The study documented contamination food-related awareness in symptoms, transmission and prevention, which shows there was confusion between Hepatitis A, E and Hepatitis B and Hepatitis E. knowledge score was calculated by counting all correct responses of a selected question of each participant. By using of independent " $t$ " test mean knowledge score was calculated.

The study documented $r^{2}=0.005$, which shows there was the influence of supply-side (ASHA) knowledge on demand-side population. However, it was not up to the mark.

\section{DISCUSSION}

The findings of the present study revealed poor knowledge regarding some important aspects of Hepatitis B infection which was $56.9 \%$ for the type of infectious disease, $20.7 \%$ for the affected organ, and $39.7 \%$

\begin{tabular}{|c|c|c|}
\hline Variable & Type & Frequency $(n=281)$ \\
\hline Age & Mean Age of participants & $24.63 \pm 3.539$ \\
\hline \multirow{2}{*}{$\begin{array}{l}\text { Current statues of } \\
\text { Mother }\end{array}$} & ANC & $144(51.2)$ \\
\hline & PNC & $137(48.8)$ \\
\hline \multirow{4}{*}{ Reproductive history } & First ANC & $56(19.9)$ \\
\hline & Live births & $201(89.3)$ \\
\hline & Institutional delivery & $218(96.8)$ \\
\hline & Normal delivery & $180(80.0)$ \\
\hline \multirow{5}{*}{ Caste } & SC & $47(16.7)$ \\
\hline & ST & $57(20.3)$ \\
\hline & OBC & $148(52.7)$ \\
\hline & Open & $29(10.3)$ \\
\hline & Illiterate & $42(14.9)$ \\
\hline \multirow{4}{*}{ Education } & $\begin{array}{c}\text { Primary/can read and } \\
\text { write }\end{array}$ & $33(11.8)$ \\
\hline & Secondary & $153(54.4)$ \\
\hline & Higher Secondary & $38(13.5)$ \\
\hline & Diploma/Graduate & $15(5.3)$ \\
\hline \multirow{5}{*}{ Type of Ration Card } & APL & $107(38.1)$ \\
\hline & BPL & $162(57.7)$ \\
\hline & Antyodaya & $2(0.7)$ \\
\hline & Any other card & $10(3.6)$ \\
\hline & Daily Wages & $23(8.2)$ \\
\hline \multirow{3}{*}{ Occupation } & Government Job & $1(0.4)$ \\
\hline & Housewife & 247 \\
\hline & Student/self employed & 10 \\
\hline
\end{tabular}

use of an infected needle on the system side, respectively. This is a matter of concern as the role of health education is to not only educate the general and high-risk population but also to prevent themselves from the spread of disease. ${ }^{19,20}$ In developing regions Hepatitis B prevalence and carrier state-observed higher than that of the general population, almost 40 to $65 \%$ of Hepatitis B virus infections are due to percutaneous occupational exposure and therefore, an awareness of various routes of transmission, prevention by vaccination and knowledge of safe practices is very essential for healthcare worker ${ }^{9,13,21}$ The study found $55.2 \%$ uptake of vaccine amongst healthcare workers, among them only $10.3 \%$ had taken complete three doses. This study reported a couple of Hepatitis B vaccination camps in selected study block for healthcare workers including grassroots healthcare workers. Regarding knowledge of Hepatitis Virus infection, it was observed that vaccination was the commonest response in both groups for prevention. It was also observed that response for contamination mode of transmission was also noted more than expected number and according to those symptoms of jaundice were the first answer when asked them for symptoms of Hepatitis B. it showed that, still the differential-difference is not seen for hepatitis A, E with Hepatitis B across the health system actors as well as among the community population. It was more in the community population; they could relate hepatitis with jaundice only irrespective of type.

Some of the literature cites that vertical transmission is the most common mode of $\mathrm{HBV}$ transmission worldwide with the risk of maternal complication, despite this it is extremely neglected in India ${ }^{10,22}$ Our 


\begin{tabular}{|c|c|c|}
\hline Variable & Type of Variable & $\begin{array}{l}\text { Frequency } \\
n=281(\%)\end{array}$ \\
\hline \multirow[t]{2}{*}{ Mean Knowledge } & Average mean score & $1.69 \pm 1.7$ \\
\hline & Heard about Hepatitis B & $110(39.1 \%)$ \\
\hline \multirow[t]{4}{*}{$\begin{array}{l}\text { General Knowledge } \\
\text { about Hep b }\end{array}$} & $\begin{array}{l}\text { ASHA as a Source of } \\
\text { information }\end{array}$ & $86(30.6)$ \\
\hline & $\begin{array}{l}\text { Other source like TV, } \\
\text { newspaper, posters }\end{array}$ & $24(8.5)$ \\
\hline & Blood related products & $6(2.1)$ \\
\hline & Infected Needle & $5(1.8)$ \\
\hline \multirow[t]{4}{*}{$\begin{array}{l}\text { Knowledge regarding } \\
\text { Transmission of Hep B }\end{array}$} & Unprotected sex & $2(0.7)$ \\
\hline & Mother to child & $5(1.8)$ \\
\hline & Skin to skin(biting) & $0(0.0)$ \\
\hline & Yellow colour skin, urine, eyes & $59(21.0)$ \\
\hline \multirow{4}{*}{$\begin{array}{l}\text { Knowledge Regarding } \\
\text { Symptoms of Hep B }\end{array}$} & Loss of appetite & $5(1.8)$ \\
\hline & Fever & $38(13.5)$ \\
\hline & Nausea/vomiting & $18(6.4)$ \\
\hline & Vaccination & $33(11.7)$ \\
\hline \multirow{3}{*}{$\begin{array}{c}\text { Knowledge Prevention } \\
\text { of Hep B }\end{array}$} & $\begin{array}{l}\text { Proper disposed of syringe/ } \\
\text { needle }\end{array}$ & $2(0.7)$ \\
\hline & Avoid Injection & $0(0.0)$ \\
\hline & Avoid multiple sex & $0(0.0)$ \\
\hline $\begin{array}{l}\text { Knowledge about child } \\
\text { vaccination }\end{array}$ & Yes & $192(68.3)$ \\
\hline
\end{tabular}

study revealed poor knowledge regarding vertical mode of transmission in antenatal/postanal mothers which was $1.8 \%$ in a community in the mentioned study, similar poor awareness found in several studies. ${ }^{17} \mathrm{We}$ observed that HBsAg reactive mothers knew about their status even though, had not enough knowledge regarding Hepatitis B, they just knew regarding necessary precaution for health facility like increase expense of delivery and risk of transmission to their partners only. They had no knowledge regarding what precaution they should follow to prevent further transmission.

The study documented a weaker influence of supply-side knowledge on the end-user level. We could find the studies regarding the influence of supply-side knowledge on the coverage of service by end level user and influence on work performance of various training for supply-side and contextual factors influence CHW performance but couldn't find much about the direct influence on knowledge of end level users from supplyside knowledge.

Based on the findings from this study which is also supported by several pieces of literature, ${ }^{3,10,23,24}$ it can be stated that it is necessary to encourage awareness campaigns, health education, proper screening of all pregnant women for HbsAg irrespective of risk factors and intensification of existing childhood immunization.

\section{CONCLUSION}

This study documented poor knowledge in both supply and demand side as well towards Hepatitis B. There is an urgent need to draw attention to the level of awareness about HBV infection, implementation of National Viral Hepatitis control program (NVHCP) activities on the ground level, and required resources to develop area context intervention for HBV prevention and address barriers for ground-level workers. It can be stated that frequent training and monitoring of healthcare workers and the community may improve in knowledge, attitude, and preventive practices, which can change Hepatitis B outcomes.

\section{ACKNOWLEDGEMENT}

The authors thank Bristol-Myseres Squibb Foundation (BMS), All India Institute of Diabetes Research (AIIDR) Ahmedabad and Taluka Health Officers as well as all the healthcare staff and Mothers (ANC/PNC) of study sites for their invaluable time and support.

\section{Limitation of the study}

The study documented the knowledge parameter for both selected populations but could not be addressed their challenges in detail, especially supply-side participants.

\section{CONFLICT OF INTEREST}

The authors declare no conflict of interest.

\section{ABBREVIATIONS}

ASHA: Accredited Social Health Activist; HBV: Hepatitis B Virus; ANC: Antenatal Care; PNC: Postnatal Care; KAP: Knowledge, Attitudes and practice.

\section{REFERENCES}

1. Hang Pham TT, Le TX, Nguyen DT, Luu CM, Truong BD, Tran PD, Toy M, Bozkurt S, So S. Knowledge, attitudes and medical practice regarding hepatitis $B$ prevention and management among healthcare workers in Northern Vietnam. PLOS ONE. 2019;14(10):e0223733. doi: 10.1371/journal.pone.0223733, PMID 31609983.

2. Dionne-Odom J, Njei B, Tita ATN. Elimination of vertical transmission of hepatitis B in Africa: a review of available tools and new opportunities. Clin Ther. 2018;40(8):1255-67. doi: 10.1016/j.clinthera.2018.05.016, PMID 29983265.

3. Mishra S, Purandre P, Thakur R, Agrawal S, Alwani M. Study on prevalence of hepatitis B in pregnant women and its effect on maternal and fetal outcome at tertiary care centre. Int J ReprodContraceptObstet Gynecol. 2017;6(6):2238. doi: 10.18203/2320-1770. ijrcog20172069.

4. Khan J, Shil A, Mohanty SK. Hepatitis B vaccination coverage across India: exploring the spatial heterogeneity and contextual determinants. BMC Public Health. 2019;19(1):1263. doi: 10.1186/s12889-019-7534-2, PMID 31510967.

5. National Viral Hepatitis Control Program (NVHCP). National Health Portal of India [cited Dec 6, 2019]. Available from: https://www.nhp.gov.in/national-viralhepatitis-control-program-(nvhcp)_pg.

6. Dev K, S KS, Abhay G, Gajanan K, Akash S, Bisure K. Knowledge and Awareness of the Health Care Workers about the Hepatitis B Infection and their Vaccination Status in a Newly Started Medical College. J Assoc Physicians India. 2018;66(12):27-30. PMID 31315320.

7. Elseviers MM, Arias-Guillén M, Gorke A, Arens HJ. Sharps injuries amongst healthcare workers: review of incidence, transmissions and costs. J Ren Care. 2014;40(3):150-6. doi: 10.1111/jorc.12050, PMID 24650088.

8. Tatsilong HO, Noubiap JJ, Nansseu JR, Aminde LN, Bigna JJ, Ndze VN, Moyou RS. Hepatitis B infection awareness, vaccine perceptions and uptake, and serological profile of a group of health care workers in Yaoundé, Cameroon. BMC Public Health. 2016;15:706. doi: 10.1186/s12889-016-3388-z. PMID 27487845.

9. Siraj F, Fareed P, Mahajan N. Assessment of knowledge attitude and practice towards hepatitis B among health care workers in a tertiary care hospital. Int J ReprodContraceptObstet Gynecol. 2016:58-61. doi: 10.18203/2320-1770.ijr$\operatorname{cog} 20151601$.

10. Abdi F. Hepatitis B and pregnancy: an update review article. World J Obstet Gynecol. 2015;4(1):1. doi: 10.5317/wjog.v4.i1.1.

11. US Preventive Services Task Force, Owens DK, Davidson KW, Krist AH, Barry MJ, Cabana M, Caughey $A B$, Doubeni CA, Epling JW, Kemper AR, Kubik M, Landefeld CS, Mangione CM, Pbert L, Silverstein M, Simon MA, Tseng CW. Wong JB. Screening for hepatitis B virus infection in pregnant women: US Preventive Services Task Force reaffirmation recommendation statement. 
JAMA. 2019;322(4):349-54. doi: 10.1001/jama.2019.9365, PMID 31334800.

12. Munivenkatappa S, Govindaraj SM. A study evaluating knowledge of and attitude towards hepatitis $B$ among pregnant women at a teaching hospital in Nellore, India. Int J ReprodContraceptObstet Gynecol. 2019;8(8):3183-8. doi: 10.18203/2320-1770.ijrcog20193532.

13. Paul $P$, Arumugam B. Knowledge and awareness regarding hepatitis $B$ infection among medical and dental students: a comparative cross sectional study. Int J Res Med Sci. 2015;2352-2356:2352-6. doi: 10.18203/2320-6012.jirms20150630.

14. Saxena S, Srivastava A, Maheshwari S, Saxena A. Assessment of knowledge \& contributing factors of accredited social health activist (ASHA) workers regarding antenatal care in Bhojipura block, district Bareilly 1. Vol. 8. p. 234.

15. (PDF) Role of ASHA in improvement of maternal health status in northern India: an urban rural comparison [cited Jul 11, 2020]. Available from: https://www. researchgate.net/publication/297992373_Role_of_ASHA_in_improvement_of_ maternal_health_status_in_northern_India_An_urban_rural_comparison.

16. Nguyen PH, Kim SS, Nguyen TT, Tran LM, Hajeebhoy N, Frongillo EA, Ruel MT, Rawat R, Menon P. Supply- and demand-side factors influencing utilization of infant and young child feeding counselling services in Viet Nam. PLOS ONE. 2016;11(3):e0151358. doi: 10.1371/journal.pone.0151358, PMID 26962856.

17. Hang Pham TT, Le TX, Nguyen DT, Luu CM, Truong BD, Tran PD, Toy M, So S. Knowledge, attitudes and practices of hepatitis B prevention and immunization of pregnant women and mothers in northern Vietnam. PLOS ONE. 2019;14(4):e0208154. doi: 10.1371/journal.pone.0208154, PMID 30969972.
18. Kashyap B, Tiwari U, Prakash A. Hepatitis B virus transmission and health-care workers: prevention, management, and awareness toward the disease. Indian J Med Spec. 2019;10(1):6. doi: 10.4103/INJMS.INJMS_40_18.

19. Ray G. Current scenario of hepatitis B and its treatment in India. J Clin Trans Hepatol. September 2017:5(3):277-96. doi: 10.14218/JCTH.2017.00024, PMID 28936409.

20. Puri P. Tackling the hepatitis B disease burdenin India. J Clin Exp Hepatol. 2014;4(4):312-9. doi: 10.1016/j.jceh.2014.12.004, PMID 25755578.

21. Shukla M, Tyagi S, Gupta NK. Hepatitis B infection and vaccination: Knowledge, Attitude and Practices among primary health care personnel in Lucknow. J Res Med Den Sci. 2016;4(1). doi: 10.5455/jrmds.20164110.

22. Malik A, Rattan A, Iraqi A, Maheshwarit V, Dhawan R. Rajyashri Sharma by. Vol 42; 1996. Hepatitis $B$ virus infection in pregnant women and its transmission to infants [cited Oct 22, 2019]. Available from: https://academic.oup.com/tropej/ article-abstract/42/6/352/1679284.

23. Sriprakash I, Anil TP. Routine prenatal Screening of Indian Women for HBsAg: benefits Derived versus Cost. Trop Doct. 1997;27(3):176-7. doi: 10.1177/004947559702700323, PMID 9227020

24. Harder KM, Cowan S, Eriksen MB, Krarup HB, Christensen PB. Universal screening for hepatitis B among pregnant women led to $96 \%$ vaccination coverage among newborns of HBsAg positive mothers in Denmark. Vaccine. 2011;29(50):9303-7. doi: 10.1016/j.vaccine.2011.10.028, PMID 22019756.

Cite this article : Memon F, Yasobant S, Patel S, Saxena D, Patel M, Patel Y. Could the System Side Knowledge towards Hepatitis B be Translated to the Demand Side: A Cross-Sectional Evaluation in Sabarkantha Gujarat. Int J Med Public Health. 2021;11(4):185-9. 